\title{
Potensi Risiko Penyebaran Kasus Demam Berdarah Dengue di Jakarta Pusat
}

\author{
Vanny Narita $^{1 *}$, Arif Lelono Arum ${ }^{2}$, Mahmudah $^{3}$, Rossticha Anjar Kesuma Tazkia ${ }^{4}$ \\ ${ }^{1,2,3,4)}$ Program Studi Biologi (Bioteknologi), Fakultas Sains dan Teknologi, \\ Universitas Al Azhar Indonesia, Jl. Sisingamangaraja, Jakarta 12110 \\ Tlp. 7244456, Fax. 7244767, *Penulis untuk korespondensi : vanny_narita@uai.ac.id
}

Abstract - Dengue Hemorrhagic Fever (DHF) caused by four virus serotypes is a disease with $A$. aegyti and $A$. albopictus mosquitoes as vectors. DHF is a recurrent and high burdened disease in Indonesia. The purpose of this study is to analyze the spreading of DHF risk in Central Jakarta based on environmental factors. The cases number data year 2000-2009 was obtained from Center of Infectious Disease Research, National Institute of Health in Research and Development. Survey was performed in 38 subdistricts using random and purposive methods. Risk indicators were used in environmental data collection. The results of this study showed similar cyclical pattern each year. March until May had a high DHF incident, while November until January had a relatively low DHF incident. In general, Central Jakarta had a medium risk potential of DHF spreading. Spearman rank analysis on adjacent areas gave various values. Subdistricts of Senen and Kemayoran had a low correlation, while subdistricts of Johar Baru and Cempaka Putih had the highest correlation among other subdistricts showing that there were vector migrations between these two subdistricts. Finally, the data obtained should be useful for minimalizing the risk of DHF spreading especially by vector control management.

Keywods - Dengue Haemorrhagic Fever, Central Jakarta, Risk of DHF spreading, Environmental Survey.

\section{PENDAHULUAN}

$\mathrm{P}$ enyakit Demam Berdarah Dengue (Dengue Hemorrhagic Fever/DBD) merupakan suatu isu kesehatan internasional yang penting, terkait dengan frekuensinya sebagai penyakit yang paling sering terjadi (Joyce, 2006). DBD dapat berkembang baik di daerah tropis dan daerah subtropis, terjadi di lebih dari 100 negara dengan 2,5 miliar orang tinggal di daerah di mana DBD endemik (Smith et al, 2009). Dengue lebih dominan menyerang anak-anak dengan angka 90\% (Teik 2001). Sampai saat ini, vaksin dengue masih pada tahap uji klinik sehingga tidak merupakan pilihan pencegahan (Guy et al, 2010)

DBD disebabkan oleh virus dengue yang ditularkan melalui gigitan vektor nyamuk Aedes aegypti dan Aedes albopictus. Empat serotipe untuk DBD yang diketahui sekarang adalah tipe DEN 1, DEN 2, DEN 3, dan DEN 4 (Wahono, 2004; Smith et al, 2009). Virus tersebut termasuk dalam group B arthropod borne viruses (arboviruses). Ke empat tipe virus tersebut telah ditemukan di berbagai daerah di Indonesia, dengan virus DEN 1 dan DEN 3 sebagai virus terbanyak yang beredar di masyarakat (Tetiasa, 2006). Kasus DBD di Indonesia diperkirakan terjadi lebih dari 50 orang dari setiap 100.000 penduduk dan berulang kali menimbulkan Kejadian Luar Biasa (Departemen Kesehatan, 2009). Seluruh wilayah Indonesia mempunyai resiko untuk terjangkit penyakit ini.

Dengue sebagai vektor virus pembawa penyakit biasanya menjadi ganas ketika musim tertentu. Oleh karena itu iklim merupakan faktor penting yang menentukan jumlah kasus DBD (Nakhapakorn \& Jirakajohnkool, 2006). Penyebaran DBD dari suatu daerah ke daerah lainnya dapat terjadi bila terdapat faktor-faktor lingkungan yang kondusif bagi vektor, daerah yang berdekatan (Bhandari \& Rhaju, 2008), serta praktek sosial budaya masyarakat yang berdomisili di daerah tersebut. Hasil penelitian yang telah dilakukan di Delhy City Zone (Bohra \& Andrianasolo, 2001) mengindikasikan bahwa sedikitnya terdapat 6 variabel, yaitu pola perumahan, frekuensi pembersihan tempat penyimpanan air, frekuensi pembersihan saluran 
air, keberadaan pot bunga atau taman rumah, proteksi terhadap nyamuk kesadaran, dan tutup penyimpanan air secara signifikan berkontribusi pada indikasi dengue.

Mengingat lingkungan berkaitan penting dengan reproduksi dan penyebaran nyamuk, penelitian ini bertujuan untuk mencari tingkat potensi penyebaran DBD di Jakarta Pusat berdasarkan analisis lingkungan. Hasil penelitian ini diharapkan akan membantu dalam pencegahan dan penanganan penyebaran DBD.

\section{MATERI DAN METODE}

\section{Daerah Penelitian}

Daerah penelitian adalah Jakarta Pusat. Jakarta Pusat mempunyai luas $48,17 \mathrm{Km}^{2}$, dengan kondisi topografi relatif datar dan secara administratif dibagi menjadi 8 kecamatan: Gambir, Sawah Besar, Kemayoran, Cempaka Putih, Johar Baru, Senen, Menteng, dan Tanah Abang.

\section{Data Kasus}

Data penderita DBD setiap tahun di Jakarta Pusat diperoleh dari Pusat Penelitian Penyakit Menular, Badan Penelitian dan Pengembangan Kesehatan, untuk tahun 2000-2009. Selain itu, data didapatkan dari Suku Dinas Kesehatan Pemerintah Daerah Jakarta sebagai perbandingan.

\section{Survei Lingkungan}

Pengumpulan data lingkungan dilakukan dengan cara survei dengan metode acak dan purposive. Data yang dikumpulkan berdasarkan indikator risiko DBD dengan penilaian menggunakan skoring (Table 1). Indikator risiko yang dipakai dalam data lingkungan adalah konstruksi dan kepadatan bangunan; keadaan sampah dan kebersihan lingkungan; keberadaan barang yang berpotensi menyebabkan air tergenang sebagai sarang nyamuk; keadaan selokan; serta keberadaan pohon dan tanaman.

\section{Statistik Deskriptif dan Nonparametris}

Data jumlah kasus di Jakarta Pusat dan hasil survei digambarkan secara deskriptif untuk melihat pola kasus setiap tahun. Korelasi Spearman Rank juga digunakan untuk mengetahui seberapa kuat hubungan dua daerah yang berdekatan memiliki kemungkinan penularan kasus melalui migrasi vektor. Korelasi ini, didefinisikan sebagai korelasi di antara ranking seluruh individu (Sprent, 2001; Sugiono, 2007; McDonald, 2009).

$$
r_{s}=1-\left[\frac{6\left(\sum D_{i}^{2}\right)}{N\left(N^{2}-1\right)}\right]
$$

Keterangan persamaan:

$$
\begin{array}{ll}
r_{s} & : \text { Rho Spearman rank } \\
D i^{2} & : \text { Nilai dari }\left(X_{i}-Y_{i}\right)^{2}, \\
X_{i} & : \text { Ranking data pertama } \\
Y_{i} & \text { : Rankning data kedua } \\
\mathrm{N} & \text { : Banyak sampel. }
\end{array}
$$

\begin{tabular}{|c|c|c|c|}
\hline No & Indikator Risiko DBD & Kisaran & $\%$ \\
\hline 1 & $\begin{array}{c}\text { Konstruksi dan kepadatan bangronan: konstruksi terbuka dan jarak antarbangunan } \\
\text { rapat }>>\text { konstruksi sedang dan ada jarak antarbangunan }>>\text { konstruksi konstruski } \\
\text { tertutup dan jarak antarbangunan jauh (tidak padat) }\end{array}$ & $1-3-5$ & 15 \\
\hline 2 & $\begin{array}{c}\text { Keadaan sampah dan kebersihan lingkungan: tempat pembuangan sampah dan } \\
\text { lingkungan bersih }>>\text { jalanan bersampah dan tempat sampah yang jarang dibersihkan } \\
>>\text { jalanan dan kawasan pemukiman bersih dan tersedianya tempat sampah yang } \\
\text { bersih dan terawat }\end{array}$ & $1-3-5$ & 5 \\
\hline 3 & $\begin{array}{l}\text { Keberadaan barang yong berpotensi menjadi ter genang: banyak terdapat kaleng dan } \\
\text { bahan plastik di luar numah dan kawasan pemukiman yang berpotensi tergenang air } \\
\text { setelah hujan, termasuk tipe atap dan bangunan }>>\text { potensi genangan tidak besar } \\
\text { berasal dari tipe atap dan bangunan, kaleng dan plastik jumlahnya tidak banyak }>> \\
\text { tidak ada barang bekas dan tipe bangunan yang tidak menyebabkan genangan }\end{array}$ & $1-3-5$ & 55 \\
\hline 4 & $\begin{array}{c}\text { Keadaan selokan: selokan hitam dan kotor mulai dari debit rendah hingga tinggi }>> \\
\text { selokan yang keruh dengan debit rendah hingga sedang }>> \\
\text { selokan yang tidak terlalu ke ruh dan aliran air relatif tenang }\end{array}$ & $1-3-5$ & 10 \\
\hline 5 & $\begin{array}{l}\text { Keberadaan pohon dan tanaman: pohon besar dan rindang, me miliki lubang di } \\
\text { bagian pohon; tanaman dalam pot yang ditanam di numah dalam jumlah besar, } \\
\text { keberadaan halaman yang sedang hingga luas }>>\text { pohon sedikit dan jumlah lubang } \\
\text { tidak terlalu banyak, kehadiran pot tidak banyak, tidak ada halaman yang luas hanya } \\
\text { sedikit berada dengan pot }>>\text { kehadiran pohon jarang tidak ada lubang pot atau } \\
\text { tanaman yang ditanam tidak ada }\end{array}$ & $1-3-5$ & 15 \\
\hline
\end{tabular}

Tabel 1. Data dan Skoring Lingkungan 


\section{HASIL}

Jumlah Penderita DBD Tahun 2000-2009

Selama 10 tahun jumlah kasus DBD mengalami peningkatan dan punurunan yang hampir sama untuk setiap bulan dalam setahun (Grafik 1). Grafik 2 memberikan gambaran umum bahwa secara keseluruhan jumlah kasus mengalami peningkatan yang berarti dari tahun 2000 hingga 2009.

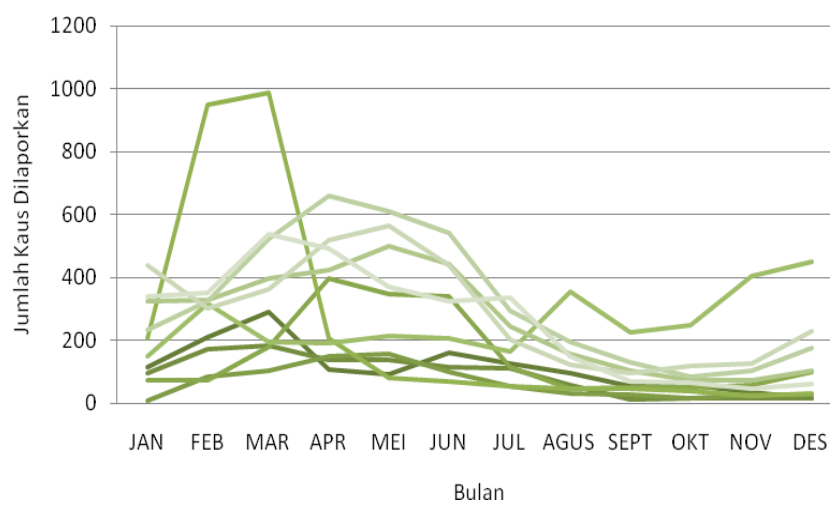

Grafik 1. Fluktuasi Jumlah Kasus DBD Setiap Bulan Dalam Satu Tahun Selama Tahun 2000-2009

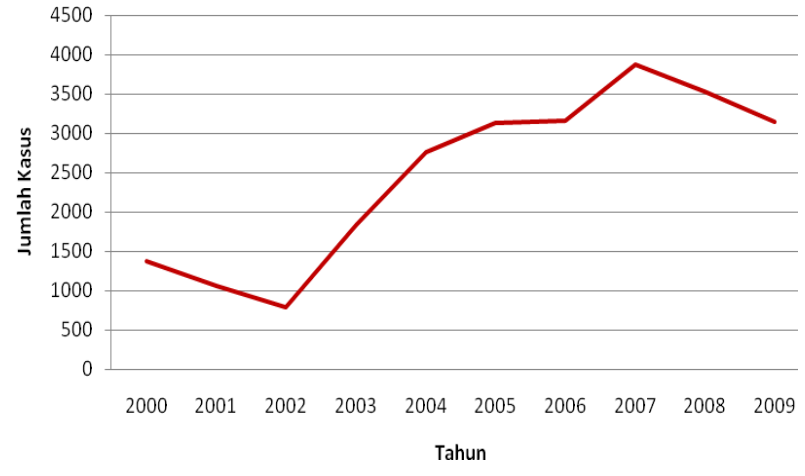

Grafik 2. Peningkatan Jumlah Kasus DBD Selama Tahun 2000-2009

Pada tahun 2001 hingga 2007 terjadi peningkatan jumlah kasus. Pada tahun 2008 dan 2009 terjadi penurunan walapun jumlah kasus yang dilaporkan masih tetap tinggi yaitu di atas 3000 kasus. Untuk jumlah kasus terbanyak dan tersedikit berdasarkan urutan, tahun 2007 masih merupakan tahun dengan jumlah kasus terbanyak dan 2002 dengan kasus paling sedikit. Informasi detil tentang jumlah kasus, dapat dilihat pada Grafik 3. Grafik 3 menggambarkan bahwa setiap tahun mempunyai jumlah kasus spesifik terbanyak atau tersedikit - yang beragam.

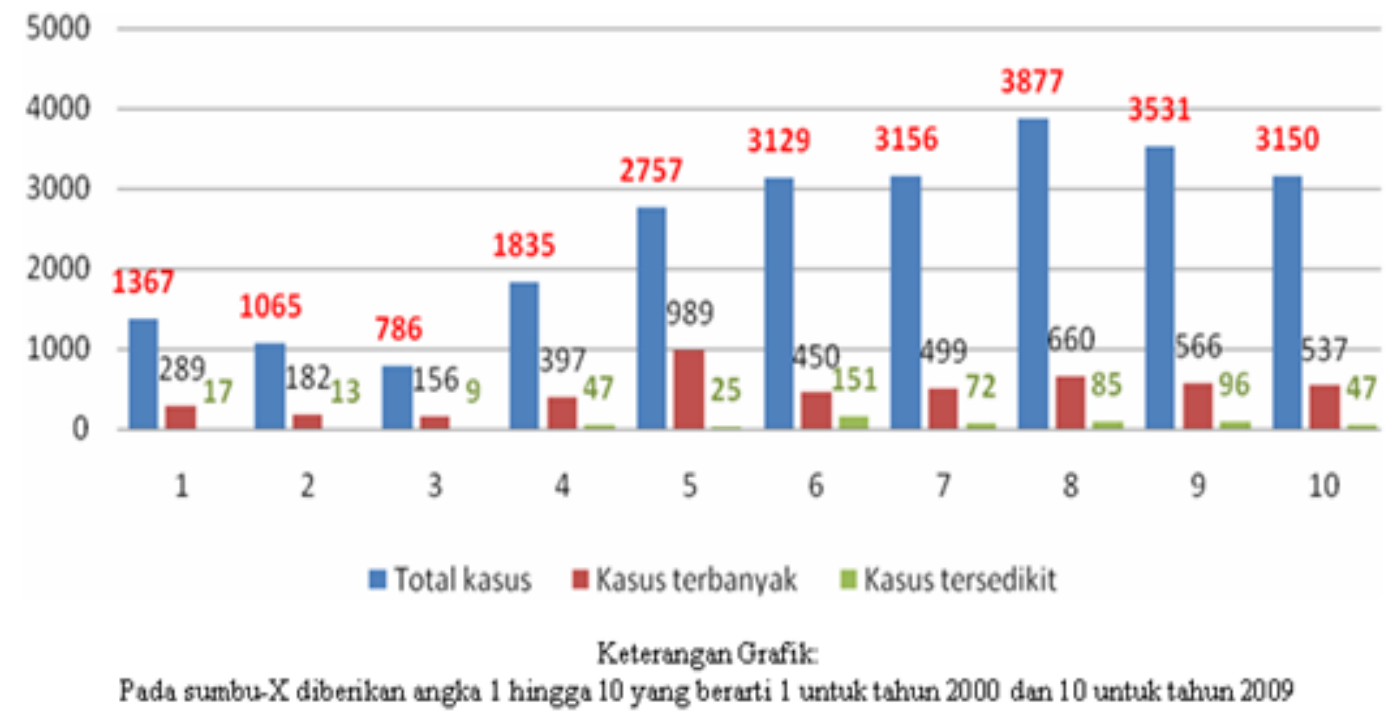

Grafik 3. Detil Informasi Jumlah Kasus DBD tahun 2000-2009 
Tabel 2. Hasil Perhitungan Data Lingkunga

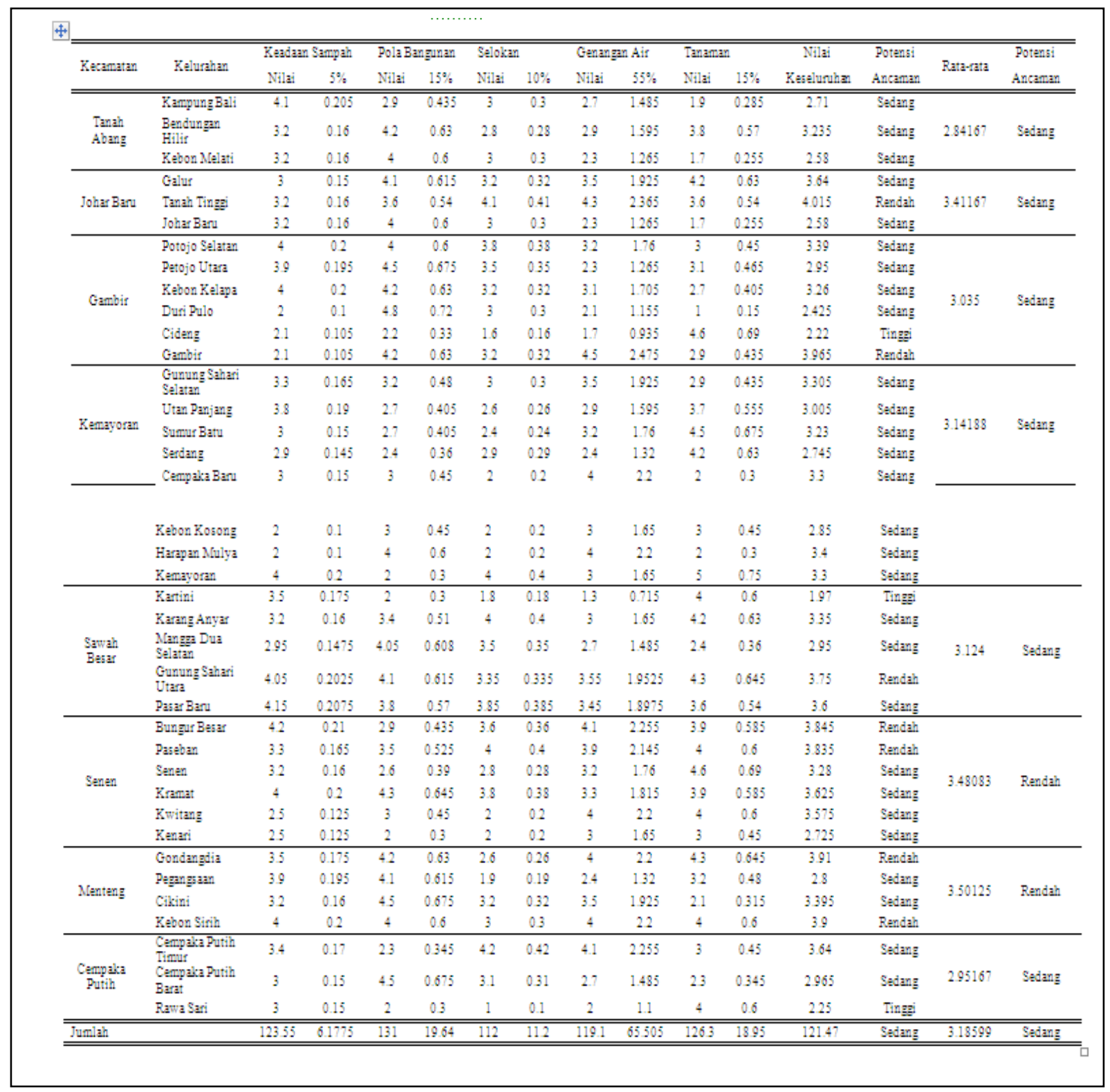


Tabel 3. Analisis Spearman Rank Kotamadya

\begin{tabular}{|c|c|c|}
\hline Kombinasi & Kombinasi & Rho \\
\hline Tanah Abang-Menteng & $\begin{array}{l}\text { Kampung Bali-Kebon Sirih } \\
\text { Kebon Melati-Gondangdia }\end{array}$ & $-1^{\mathrm{ss}}$ \\
\hline Tn.Abang-Gambir & $\begin{array}{l}\text { Kampung Bali-Petojo Selatan } \\
\text { Kampung Bali-Cideng } \\
\text { Kampung Bali-Gambir } \\
\text { Kampung Bali-Duri Pulo } \\
\end{array}$ & 0.5 \\
\hline Menteng-Senen & $\begin{array}{l}\text { Gondangdia - Kenari } \\
\text { Pegangsaan - Kenari } \\
\text { Pegangsaan - Paseban } \\
\text { Pegangsaan - Cikini } \\
\text { Cikini - Kwitang } \\
\text { Kebon Sirih - Kwitang } \\
\text { Kebon Sirih -Senen } \\
\end{array}$ & $1.214286^{\&}$ \\
\hline Menteng - Gambir & $\begin{array}{l}\text { Gondangdia - Petojo Selatan } \\
\text { Gondangdia - Gambir } \\
\text { Kebon Sirih - Cideng } \\
\text { Kebon Sirih - Gambir }\end{array}$ & 0.35 \\
\hline Senen - Sawah Besar & $\begin{array}{l}\text { Kwitang - Pasar Baru } \\
\text { Bungur Besar - Pasar Baru } \\
\text { Senen - Pasar Baru }\end{array}$ & 0.75 \\
\hline Senen - Kemayoran & $\begin{array}{l}\text { Bungur Besar - Kemayoran } \\
\text { Bungur Besar - Harapan Mulya } \\
\text { Bungur Besar - Utan Panjang } \\
\text { Senen - Pasar Baru }\end{array}$ & 0.35 \\
\hline Senen - Johar Baru & $\begin{array}{l}\text { Kramat - Tanah Tinggi } \\
\text { Kramat - Johar Baru } \\
\text { Kwitang - Tanah Tinggi } \\
\text { Paseban - Johar Baru } \\
\end{array}$ & -0.65 \\
\hline Johar Baru - Kemayoran & $\begin{array}{l}\text { Galur - Harapan Mulya } \\
\text { Galur - Cempaka Baru }\end{array}$ & $0.5^{\mathrm{ss}}$ \\
\hline Johar Baru - Cempaka Putih & $\begin{array}{l}\text { Galur - Cempaka Putih Timur } \\
\text { Johar Baru - Rawasari } \\
\text { Galur - Cempaka Putih Barat }\end{array}$ & 0.875 \\
\hline Cempaka Putih - Kemayoran & $\begin{array}{l}\text { Cempaka Putih Timur - Sumur Batu } \\
\text { Cempaka Putih Barat - Serdang }\end{array}$ & $1^{\mathrm{ss}}$ \\
\hline Gambir - Sawah Besar & $\begin{array}{l}\text { Kebon Kelapa - Pasar Baru } \\
\text { Gambir - Petojo Utara } \\
\text { Gambir - Pasar Baru }\end{array}$ & -0.625 \\
\hline Sawah Besar - Kemayoran & $\begin{array}{l}\text { Gunung Sahari Utara - Kemayoran } \\
\text { Gunung Sahari Utara - Kebon Kosong } \\
\text { Gunung Sahari Utara - Utan Panjang }\end{array}$ & 0.5 \\
\hline
\end{tabular}


Hasil untuk survei lingkungan menggambarkan Jakarta Pusat memiliki potensi yang sedang untuk terjadinya kasus DBD (Tabel 2). Kecamatan Menteng dan Senen memiliki potensi risiko rendah, sedangkan Kelurahan Cideng (Gambir), Kartini (Sawah Besar), dan Rawa Sari (Cempaka Putih) memiliki potensi penyebaran paling tinggi. Tanah Tinggi (Johar Baru), Gambir (Gambir), Gunung Sahari Utara (Sawah Besar), Bungur Besar (Senen), Paseban (Senen), Gondangdia (Menteng), dan Kebon Sirih (Menteng) merupakan daerah dengan potensi penyebaran yang rendah.

Untuk nilai lingkungan, angka yang semakin tinggi menggambarkan keadaan lingkungan yang semakin baik, artinya tidak mendukung perkembangbiakan nyamuk. Kategori diambil dari nilai karakteristik lingkungan, di mana nilai tertinggi dikurangi nilai terrendah. Dalam hal ini 3,501-2,841=0,659. Kemudian 0,659 dibagi 3 kategori, untuk rendah, sedang, dan tinggi. Kategori akan berbeda dengan skala perhitungan awal untuk survei. Hal ini hanya untuk menggambarkan pada level mana angka nilai lingkungan berada jika dibandingkan dengan sesamanya.

Analisis daerah yang berdekatan menggunakan spearman rank memberikan nilai yang bervariasi (Tabel 3). Kecamatan Johar Baru dan Cempaka Putih mempunyai korelasi yang paling tinggi dan Senen - Kemayoran dengan korelasi paling rendah.

\section{PEMBAHASAN}

Kasus DBD di Jakarta Pusat terus mengalami peningkatan terutama selama tahun 2002 hingga 2007 (Arum \& Islamic, 2010). Antara bulan Maret hingga Mei dalam sepuluh tahun terakhir dilaporkan terjadi DBD dengan jumlah kasus terbanyak, dan antara November sampai Januari terdapat kasus DBD paling kecil. Hal ini dapat berkaitan dengan faktor cuaca yang terjadi, terutama hujan yang menyediakan genangan air bagi perindukan nyamuk vektor. Pola siklus ini terjadi pula di berbagai daerah endemik DBD seperti di Thailand dan Ghuangzhou, China (Wongkoon et al, 2007; Lu et al, 2009).

Tabel 2 memberikan informasi mengenai potensi penyebaran kasus DBD di setiap kelurahan di Jakarta. Kelurahan Cideng, Kecamatan Gambir, Kartini (Sawah Besar), dan Rawa Sari (Cempaka Putih) merupakan kelurahan dengan potensi penyebaran paling tinggi, diindikasikan dengan nilai data lingkungan yakni indikator risiko DBD. Tanah Tinggi (Johar Baru), Gambir (Gambir), Gunung Sahari Utara (Sawah Besar), Bungur Besar
(Senen), Paseban (Senen), Gondangdia (Menteng), dan Kebon Sirih (Menteng) merupakan daerah dengan potensi penyebaran yang rendah. Di tingkat kecamatan, hanya Kecamatan Senen dan Menteng yang mendapat rata-rata nilai indikator risiko terbesar (rendah). Potensi penyebaran ini menggambarkan bahwa kasus DBD di daerah dengan potensi penyebaran tinggi diakibatkan adanya situasi lingkungan yang mendukung reproduksi nyamuk (Allen \& George, 2003). Selain itu apabila terjadi satu kasus, penyebaran virus dapat terjadi secara cepat dibandingkan dengan daerah lain. Hal ini penting untuk diketahui dalam manajemen pencegahan dan penanggulangan $\mathrm{DBD}$, misalnya melalui pengasapan atau abatisasi.

Beberapa indikator yang sulit diperbaiki untuk meminimalkan risiko DBD, misalnya pola perubahan prilaku karena sifatnya lebih permanen seperti yang telah dipelajari di Mataram (Fathi \& Wahyuni, 2005). Oleh karena itu, penekanan nilai risiko akan lebih efektif dengan cara mengurangi atau mengelola sampah serta keberadaan barang dan vegetasi agar tidak menimbulkan genangan setelah hujan seperti yang pernah diteliti di daerah endemic DBD di Surabaya (Yudhastuti \& Vidiyani, 2005).

Selanjutnya nilai lingkungan yang diperoleh dalam studi ini dikorelasikan antar daerah yang berdekatan untuk mengetahui besar hubungan potensi risikonya. Peningkatan jumlah kasus di satu daerah dapat menyebabkan peningkatan di daerah yang lain (tanda positif) dan sebaliknya (tanda negatif) karena adanya migrasi vektor. Untuk memeriksa dua kecamatan, dilakukan pemeriksaan di tingkat kelurahan (Tabel 3).

Hasil analisa menunjukkan bahwa Kecamatan Johar Baru dan Cempaka Putih memiliki korelasi yang besar, yakni 0,875 . Hal ini berarti kasus yang terjadi di dua kecamatan tersebut mempunyai hubungan erat dengan migrasi vektor. Korelasi terbesar disusul oleh kombinasi Senen-Sawah Besar dengan angka 0,75. Kecamatan Senen-Johar Baru dan Gambri-Sawah Besar menunjukkan korelasi negatif. Artinya terdapat kemungkinan bahwa kenaikan di satu kecamatan berkorelasi dengan penurunan di kecamatan yang lain, dengan angka yang sama yakni $-0,625$. Kecenderungan korelasi yang didapat adalah sedang dengan kisaran 0,25 hingga 0,85 (apabila nilai maksimun dan minimun diabaikan). Kombinasi Menteng-Senen di atas memberikan paling banyak jumlah kelurahan yang diuji.

Penggunaan korelasi di dalam kecamatan ini adalah untuk memberikan pemahaman tentang kemungkinan penyebaran vektor. Nyamuk dapat 
berpindah ke daerah yang dekat, misal antar kelurahan yang berdekatan. Penelitian yang lebih menyeluruh serta dilengkapi dengan pemetaan resiko DBD menggunakan analisa Geographical Information System seperti yang telah dilakukan di India, Malaysia, Kolombia, Brazil, bahkan di Jepara - Indonesia (Bohra \& Adrianasolo, 2001; Seng et al, 2005; Hariyana, 2007; Siqueira-Junior et al, 2008; Arboleda et al, 2009) dapat memberikan informasi penting bagi upaya pencegahan maupun penanganan penyebaran kasus DBD secara efektif di seluruh Indonesia.

\section{KESIMPULAN}

Hasil penelitian ini menunjukkan kasus DBD selama kurun waktu 200-2009 memiliki pola naik turun berulang setiap tahunnya yang relatif serupa. Bulan Maret hingga Mei adalah bulan dengan kasus DBD tertinggi, sedangkan bulan November hingga Januari tercatat kasus DBD yang relatif rendah. Secara keseluruhan, Jakarta Pusat memiliki potensi resiko penyebaran DBD sedang. Analisis daerah yang berdekatan menggunakan spearman rank memberikan nilai yang bervariasi. Kecamatan Senen dan Kemayoran memiliki korelasi paling rendah, sedangkan Kecamatan Johar Baru dan Cempaka Putih memiliki korelasi yang paling tinggi yang menunjukkan terjadinya migrasi vektor antara dua kecamatan ini.

Khusus pada kecamatan dengan korelasi tinggi, disarankan segera dilakukan peningkatan kualitas manajemen sampah, keberadaan barang-barang yang berpotensi mengumpulkan genangan air dan vegetasi agar menekan angka reproduksi dan migrasi vektor. Akhirnya studi komprehensif dilengkapi dengan pemetaan resiko DBD menggunakan analisa Geographical Information System perlu dilakukan untuk membantu menyediakan informasi epidemiologi yang akurat serta manajemen lingkungan dan pengendalian vektor yang tepat.

\section{UCAPAN TERIMA KASIH}

Penelitian ini dibiayai oleh Lembaga Pengkajian dan Pengembangan Pendidikan Penelitian dan Pengabdian Masyarakat, Universitas Al Azhar Indonesia (UAI). Untuk dukungan dan bantuan Dekan Fakultas Sains dan Teknologi Universitas UAI, Ketua Program Studi Biologi UAI, dr. Whinie Lestari, MBiomed (Balitbangkes Depkes), serta mahasiswa/i Program Studi Biologi UAI yang turut berpartisipasi dalam pengumpulan survey, kami ucapkan terima kasih yang sebesar-besarnya.

\section{DAFTAR PUSTAKA}

[1] Allen, T.R. \& George, Y.L. (2003). Integrating Remote Sensing, Terrain Analysis, and Geostatistics for Mosquito Surveillance and Control.

[2] Arboleda, S., et al. (2009). Mapping Environmental Dimention of Dengue Fever Transmission Risk in the Aburrá Valley, Colombia. International Journal of Environmental Research and Public Health. 6: 3040-3055.

[3] Arum, A.R. \& Islamie, M.A. (2010). Analisis Statistik Kasus Deman Berdarah Dengue di Jakarta. Ritektra. 1: 41-48.

[4] Bhandari, K.P. \& Raju P.L.N. (2008). Application of GIS Modelling For Dengue Fever Prone Area Based On Socio-Cultural And Environmental Faktors: A Case Study of Delhi City Zone. Page 165-169.

[5] Bohra, A. \& Andrianasolo, H. (2001). Application of GIS in Modeling of Dengue Risk Based on Sociocultural Data: Case of Jalore, Rajasthan, India. Dengue Bulletin, 25: 92-102.

[6] Departemen Kesehatan. (2009). Buku Data 2008. Subdit. Surveilans Epidemiologi Dit. SEPIM KESMA Ditjen. PP \& PL Depkes RI.

[7] Fathi, S.K. \& Wahyuni, C.U. (2005). Peran Faktor Lingkungan dan Perilaku terhadap Penularan Deman Berdarah Dengue di Kota Mataram. Jurnal Kesehatan Lingkungan, 2: 1 - 10.

[8] Guy, B. et al. (2010). Development of Sanofi Pasteur Tetravalent Dengue Vaccine. Hum Vaccin $6(9)$

[9] Hariyana, B. (2007). "Pengembangan Sistem Informasi Surveilans Epidemiologi Demam Berdarah Dengue Untuk Kewaspadaan Dini dengan Sistem Informasi Geografis di Wilayah Dinas Kesehatan Kabupaten Jepara (Studi Kasus di Puskesmas Mlonggo I)." Tesis. Magister Ilmu Kesehatan Masyarakat, Konsentrasi Sistem Informasi Manajemen Kesehatan, Program Pasca Sarjana, Universitas Diponegoro, Semarang.

[10] Joyce, J.A. (2006). The Treatment of Dengue Hemorrhagic Fever. USA: Aethlon Medical, Inc.

[11] Lu, L. et al. (2009). Time Series Analysis of Dengue Fever and Weather in Guangzhou, China. BMC Public Health 2009, 9:395.

[12] McDonald, JH. (2009). Handbook of Biological Statistics $\left(2^{\text {nd }}\right.$ ed.) Sparky House Publishing, Baltimore, Maryland.

[13] Nakhapakorn, K. \& Jirakajohnkool, S. (2006). Temporal and Spatial Autocorrelation Statistiks of Dengue Fever. Dengue Bulletin,30: 177-183. 
[14] Seeng, S.B., et al. (2005). Geostatistical Modelling and Mapping of Epidemiology of Dengue Fever in Johor State, Malaysia. SIRC.

[15] Setiati, T.E. et al (2006). Changing Epidemiology of Dengue Haemorrhagic Fever in Indonesia. Dengue Bulletin, 30: 1-12.

[16] Siqueira-Junior et al. (2008). Spatial point analysis based on dengue surveis at household level in central Brazil. BMC Public Health 2008, 8:361.

[17] Smith, M.J. et al. (2009). Geospatial Analysis: A Comprehensive Guide to Principles, Techniques and Software Tools. Third Edition.

[18] Sprent, P. (2001). Metode Statistik Nonparametris terapan (Penerjemah: Osman, E.R.). Jakarta: Penerbit Universitas Indonesia.

[19] Sugiono. (2007). Statistika Untuk Penelitian. Bandung: CV Alfabet.
[20] Teik, O.C. (2001). A Guide to DHF/DSS Management: The Singapore Experience. Dengue Bulletin. 25: 45-49.

[21] Wahono, J. T. (2004). Kajian Masalah Kesehatan: Demam Berdarah Dengue. Jakarta: Badan Penelitian dan Pengembangan Kesehatan, Departemen Kesehatan.

[22] Wongkoon, S. et al. (2007). Predicting DHF Incidence in Northern Thailand Using Time Series Analysis Technique. World Academy of Science, Engineering and Technology. 32: 216-220

[23] Yudhastuti, R. \& Vidiyani, A. (2005). Hubungan Kondisi Lingkungan, Kontainer, dan Perilaku Masyarakat dengan Keberadaan Jentik Nyamuk Aedes Aegypti di Daerah Endemis Demam Berdarah Dengue Surabaya. Jurnal Kesehatan Lingkungan, 1: 170-18 